\title{
Molecular Docking Study of Akar Kuning (Arcangelisia flava) Secondary Metabolites as Src Inhibitor
}

\author{
Mohammad Rizki Fadhil Pratama ${ }^{1 *}$, Evi Mulyani ${ }^{1}$, Suratno ${ }^{2}$ \\ ${ }^{1}$ Department of Pharmacy, Faculty of Health Sciences, Universitas Muhammadiyah Palangkaraya. Palangka Raya, \\ Indonesia \\ ${ }^{2}$ Department of Medical Laboratory Technology, Faculty of Health Sciences, Universitas Muhammadiyah Palangkaraya. \\ Palangka Raya, Indonesia
}

\begin{abstract}
Proto-oncogene tyrosine-protein kinase $\mathrm{Src}$ is also known as simply Src, a tyrosine kinase protein which is one of the targets in various cancer therapies such as leukemia. Meanwhile, akar kuning (Arcangelisia flava) has gained significant attention as a medicinal plant that has a cytotoxic effect on various types of cancer cells. This study aims to determine the potential of secondary metabolites of akar kuning as Src inhibitors. Molecular docking was carried out using Autodock Vina 1.1.2 with $2 \mathrm{HCK}$ receptors, that quercetin and dasatinib were used as reference ligands. The docking results showed that the lowest free energy of binding was shown by berberine with a $\Delta G$ value of $-9.0 \mathrm{kcal} / \mathrm{mol}$, exceeded quercetin and dasatinib. However, the highest amino acid of the protein interacts similarly to quercetin and dasatinib was produced by jatrorrhizine, with $93.33 \%$ and $73.91 \%$ of similarity, respectively. Interestingly, berberine is the ligand with the third-highest similarity after jatrorrhizine and palmatine, while jatrorrhizine has the second-highest affinity after berberine. The results concluded that both berberine and jatrorrhizine is predicted to be used as Src inhibitors.
\end{abstract}

Keywords: Akar kuning, Berberine, Jatrorrhizine, Src Inhibitor

\section{INTRODUCTION}

Currently, research related to the efficacy of akar kuning (Arcangelisia flava) has recently been increasingly carried out, especially after the findings of high school students from Central Kalimantan who said that akar bajakah, one variant of the same genus with akar kuning could be used in breast cancer therapy. In contrast to akar bajakah which is still being investigated at the primary level, research related to akar kuning has been done long enough before and has passed several pre-clinical trials, one of which is to determine its efficacy as an anticancer (Haryanti \& Widiyastuti, 2017). The spectrum of anticancer activity of the akar kuning itself is quite extensive, where the activity is shown against several types of cancer cells, including breast cancer and leukemia (Rad, et al., 2017).

Several receptor proteins act as regulators in various cancer cases, such as estrogen and human epidermal growth factor receptor 2 (HER2) in breast cancer, as well as proto-oncogene tyrosine-protein

Submitted: September 9, 2019

Revised: September 26, 2019

Accepted: September 27, 2019

*Corresponding author: m.rizkifadhil@umpalangkaraya.ac.id 
kinase Src (or simply Src) in leukemia (Pratama \& Sutomo, 2018; Mahavorasirikul, et al., 2010). Src itself is a protein that acts as a regulator in the process of cell proliferation, where the protein plays a role in the signaling process through TLR pathways. Src is included in tyrosine-kinase and plays a role in the phosphorylation of the amino acid tyrosine from other kinases (Ardito, et al., 2017). The increase in activity and the number of Src is known to be related to cancer progression by promoting other signals (Bhullar, et al., 2018). Various Src inhibitors, such as dasatinib and quercetin, have been discovered and developed in cancer therapies such as leukemia (Talpaz, et al., 2018).

Akar kuning is known to have a variety of secondary metabolites that have anticancer activity. One of the most widely studied is berberine, a protoalkaloid with a quaternary ammonium group that is known to have anticancer activity against several types of cancer cells (Lu, et al., 2012). Several other secondary metabolites of akar kuning are also known to have an anticancer activity such as jatrorrhizine and palmatine (Qiu, et al., 2018; Long, et al., 2019). Previous research has shown that secondary metabolites have potential as inhibitors in various cancer receptors such as epidermal growth factor receptor (EGFR) and HER2 with quite possible results (Pratama, 2016; Pratama \& Pratomo, 2017). Considering the similarity of EGFR protein structure with Src as a fellow tyrosine kinase that plays a role in cell proliferation signaling, it is probable that secondary metabolites from akar kuning can also be inhibitors of Src protein (Wee \& Wang, 2017). This study aims to determine the potential of secondary metabolites of akar kuning as Src inhibitors. The method used is molecular docking with a targeted-docking approach compared to known Src inhibitors such as quercetin and dasatinib.

\section{METHODS}

The hardware used was the ASUS A46CB series Ultrabook with an Intel ${ }^{\mathrm{TM}}$ Core i5-
3337U@1.8 GHz and Windows 7 Ultimate 64-bit SP-1 operating system. The software used was HyperChem 8.0.8 from Hypercube Inc., OpenBabel 2.4.1 from OpenBabel.org., AutoDockTools 1.5.6 and Autodock Vina 1.1.2 software from The Scripps Research Institute Inc., PyMOL 2.3.1 from Schrodinger LLC., UCSF Chimera 1.13.1 from University of California, San Francisco, and Discovery Studio Visualizer 19.1.0 from Dassault Systems Biovia (Trott \& Olson, 2010; O'Boyle, et al., 2011; Yuan, et al., 2017; Pettersen, et al., 2004). Information on three-dimensional structures of receptor proteins obtained from the website of Protein Data Banks (http://rcsb.org).

The test ligand used were 11 secondary metabolites of akar kuning as shown in Figure 1 consisting of 2-dehydroaxyarcangelisinol (1), 6-hydroxyarcangelisin (2), 6-hydroxyfibleucin (3), 6-hydroxyfibraurin (4), berberine (5), columbamine (6), fibleucin (7), fibraurin (8), jatrorrhizine (9), palmatine (10), and tinophyllol (11) (Pratama, et al., 2018; Ginovyan, et al., 2017; Yi, et al., 2018). Also used is the reference ligand, dasatinib, a small-molecule tyrosine kinase inhibitor that has been used and is marketed as an Src inhibitor in the treatment of leukemia. The two-dimension structure of all test ligands was drawn using HyperChem 8.0.8. Ideal conformation of all test ligands has been provided by performing energy minimization by $a b$ initio method basis set 3-21G, which approaching ideal conformation of these compounds in nature (Ferreira, et al., 2015). Optimized structures format changed from.log to.pdb using Open Babel 2.4.1. In this study, Autodock Vina 1.1.2 was used as a Docking program. The accuracy and speed of the calculation process are the main advantages of the docking process with Autodock Vina, where the disadvantages are that it requires other software to interpret the results (Pagadala, et al., 2017). For the observation of docking results in two dimensions using Discovery Studio Visualizer 19.1.0. The advantage of the software is that the type of amino acid interactions that occur can be observed in de- 
tail. All ligands then are given the charge and set torque by default using software AutoDockTools 1.5.6 (Forli, 2015).

The molecular structure of Src receptor was obtained from the website of Protein Data Bank (PDB) http://www.rscb.org with PDB ID 2HCK. The receptor is in the form of a dimer with a resolution of $3 \AA$ bind to a reference ligand of quercetin, a flavonoid that is known to have a variety of pharmacological activities, one of which is as an anticancer (Sicheri, et al., 1997). The receptor was downloaded in.pdb format and then removed the unused portion, added the non-polar hydrogen group, given the charge, and set the grid box size as well as coordinate using software AutoDockTools 1.5.6. The grid box size was obtained through the orientation process until the smallest grid box was obtained with an root-mean-square deviation (RMSD) value below $2 \AA$. The used chain-domain of the receptor is the active site which is bind to Src inhibitor, in this case, quercetin (Morris, et al., 2009; Ramirez \& Caballero, 2018).

The validation process was carried out by the re-docking method, where the quercetin from the 2HCK receptor was extracted, added the non-polar hydrogen group, given the charge, torque and rotational bond was adjusted, then saved in the .pdbqt format. The reference ligand was then re-docked at the grid box position and size predetermined from the orientation result (Megantara, et al., 2016). The parameters observed in the validation process are
RMSD of reference ligand at the selected binding site. The RMSD score illustrates the average difference in ligand atom position redocking with crystallographic results, while the smaller the RMSD value indicates the accuracy of the docking results that approaching the results of crystallography. The maximum value of RMSD which is often the benchmark for the docking validation process is 2 $\AA$, where the RMSD value less than $2 \AA$ indicating a valid docking result (Castro-Alvarez, et al., 2017; Pagadala, et al., 2017).

The primary objective of the molecular docking is to identify the energetically favorable binding modes or binding pose of test ligands into the target receptor's selected binding site (Atkovska, et al., 2014). Docking for all test ligands performed in the same way as the validation process with similar size and position of the grid box. The main parameter used in docking process with Autodock Vina was the free energy of binding $(\Delta G)$ as affinity marker and amino acids residues as interaction marker (Forli, et al., 2016; Natesan, et al., 2012). The more negative $\Delta \mathrm{G}$ shows the higher ligand affinity for the selected binding site of the receptor. The amino acids residues of all test ligand then compared with reference ligand to assess the similarity of interaction between test and reference ligand. The more similar amino acid residues indicate a higher probability that the test ligand will have a similar type of interaction with the reference ligand (Pratama, et al., 2018; Singh, et al., 2016).

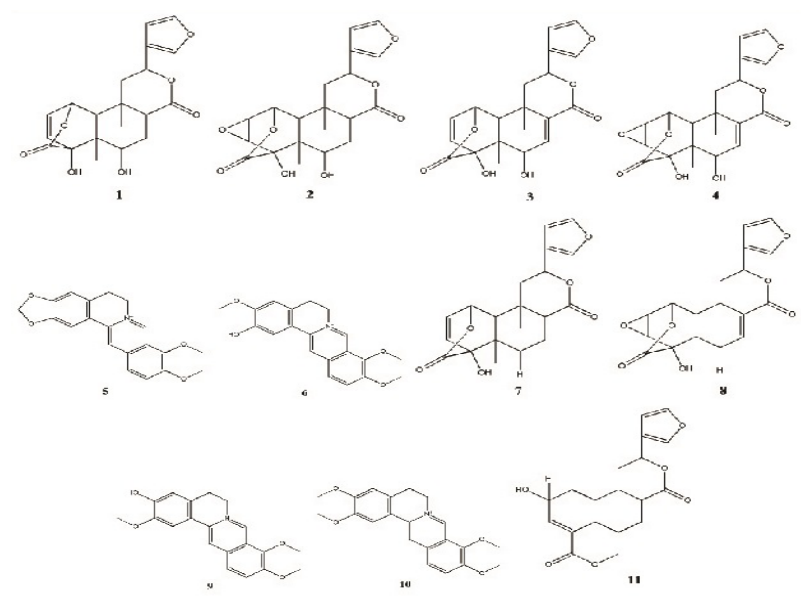

Figure 1. Structure of known secondary metabolites from akar kuning (Pratama, et al., 2018) 


\section{RESULTS}

Redocking results from this study were provided RMSD score of $1.210 \AA$, indicated that the receptor $2 \mathrm{HCK}$ used was valid for docking purpose. Visualization of ligand overlays resulting from redocking with co-crystal ligands from crystallographic results is presented in Figure 2. Other parameters observed in the validation process are $\Delta \mathrm{G}$ and amino acid residues, including size and grid box coordinates, as shown in Table 1.

The docking of the eleven test ligands and dasatinib showed exciting results that several test ligands have an affinity that is comparable to the dasatinib or quercetin as ligand references. Berberine, columbamine, jatrorrhizine, and palmatine showed $\Delta \mathrm{G}$, which is comparable or more negative than quercetin, where berberine even has a more negative $\Delta \mathrm{G}$ value than dasatinib, as presented in Table 2. Practically, these results indicate that berberine has the potential to compete with both dasatinib and quercetin as inhibitors at Src binding sites. However, the $\Delta \mathrm{G}$ value of berberine with dasatinib itself only has a difference of $0.1 \mathrm{kcal} / \mathrm{mol}$, each worth $-9.0 \mathrm{kcal} / \mathrm{mol}$ and $-8.9 \mathrm{kcal} / \mathrm{mol}$, respectively. On the other hand, jatrorrhizine has the next most negative $\Delta \mathrm{G}$ value with a value of $-8.8 \mathrm{kcal} / \mathrm{mol}$, again only having a $0.1 \mathrm{kcal} / \mathrm{mol}$ difference with dasatinib. At a glance, it can be concluded that both berberine and jatrorrhizine have the free energy of binding that is similar at the binding site of Src.

Observations of amino acid residues show exciting results, as presented in Tables 3. Dasatinib, which is already known to have acted as an Src inhibitor, has $100 \%$ amino acid residues similar to quercetin, where the similarity to the type of interaction that also occurs quite high at $60 \%$. While from the test ligands, the highest similarity was shown by jatrorrhizine, with $93.33 \%$ similar amino acid residues and $53.33 \%$ similar types of interactions compared to quercetin. However, berberine itself also shows a reasonably high similarity to both quercetin and dasatinib. Besides, both jatrorrhizine and berberine have relatively similar binding motives, as can be seen visually in Figure 3 and Figure 4.

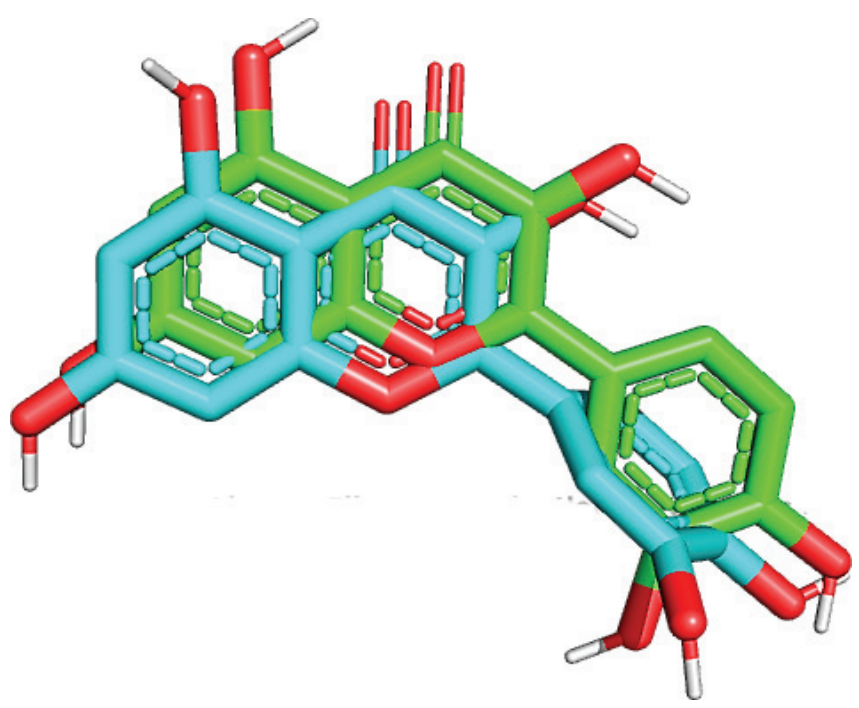

Figure 2. Overlays of redocking (blue) ligands with co-crystal ligands from crystallography (green) at $2 \mathrm{HCK}$ receptor; $\mathrm{RMSD}=1.210 \AA$ 


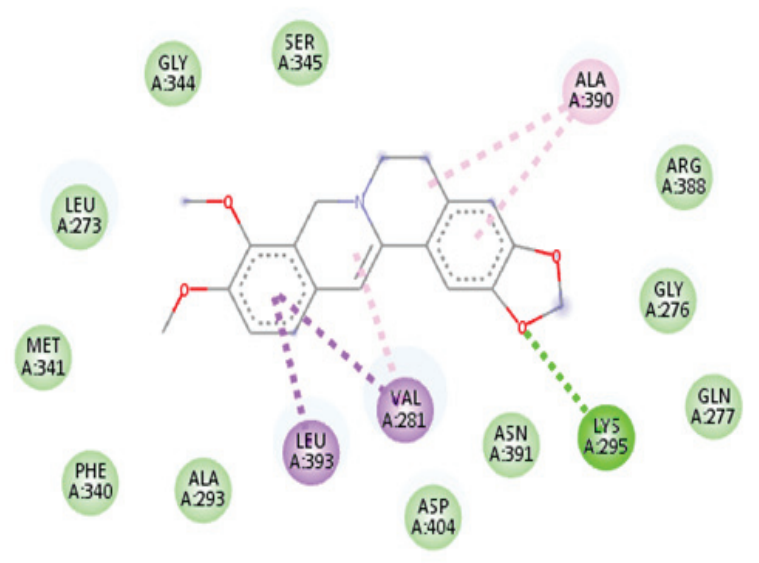

Figure 3. Interactions of berberine in amino acid residues from $2 \mathrm{HCK}$ receptors

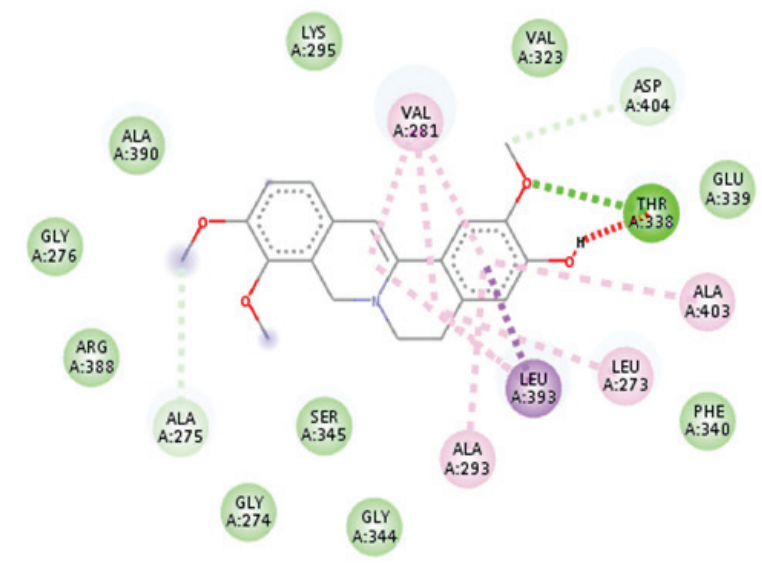

Figure 4. Interactions of jatrorrhizine in amino acid residues from $2 \mathrm{HCK}$ receptors

Table 1. Results of the validation process of $2 \mathrm{HCK}$ receptor

\begin{tabular}{|c|c|}
\hline Parameters & Value \\
\hline PDB ID & $2 \mathrm{HCK}$ \\
\hline Reference ligand & Quercetin \\
\hline \multirow[t]{2}{*}{ Grid box size $(\AA)$} & $40 \times 30 \times 30$ \\
\hline & $x: 30.556$ \\
\hline \multirow[t]{2}{*}{ Grid box position } & $y: 45.903$ \\
\hline & z: 99.090 \\
\hline RMSD $(\AA)$ & 1.21 \\
\hline \multirow[t]{8}{*}{$\Delta \mathrm{G}(\mathrm{kcal} / \mathrm{mol})$} & -8.5 \\
\hline & 273-Leu* \\
\hline & $274-$ Gly $^{* *}$ \\
\hline & $281-\mathrm{Val}^{* * *}$ \\
\hline & 293-Ala* \\
\hline & $323-\mathrm{Val}^{* *}$ \\
\hline & 338-Thr ${ }^{* *}$ \\
\hline & 339-Glu*t+*t \\
\hline \multirow[t]{8}{*}{ Amino acid residues } & $340-\mathrm{Phe}^{* *}$ \\
\hline & $341-$ Met $^{* *}$ \\
\hline & 344-Gly \\
\hline & $345-$ Ser $^{*+* t+x}$ \\
\hline & 390-Ala** \\
\hline & 393-Leu**t \\
\hline & 403-Ala* \\
\hline & 404-Asp ${ }^{* *}$ \\
\hline
\end{tabular}

*Alkyl/Pi-alkyl interaction; **Van der Waals interaction; ***Pi-sigma interaction; ${ }^{* * * *}$ Hydrogen bond 
Pratama, et al., 2019

Indones. J. Cancer Chemoprevent., 10(3), 122-130

Table 2. Results of the docking process of test ligands at binding site of $2 \mathrm{HCK}$ receptor

\begin{tabular}{|c|c|c|c|c|c|c|c|c|c|c|c|c|}
\hline Ligand & Das & 1 & 2 & 3 & 4 & 5 & 6 & 7 & 8 & 9 & 10 & 11 \\
\hline $\begin{array}{c}\Delta \mathrm{G} \\
(\mathrm{kcal} / \mathrm{mol})\end{array}$ & -8.9 & -7.8 & -7.4 & -7.4 & -8.2 & -9.0 & -8.5 & -7.9 & -7.5 & -8.8 & -8.5 & -7.2 \\
\hline \multirow{29}{*}{$\begin{array}{l}\text { Amino } \\
\text { acid } \\
\text { residues }\end{array}$} & - & $\begin{array}{l}\text { 117- } \\
\text { Glu****** }\end{array}$ & $\begin{array}{l}117- \\
\text { Glu**+*** }\end{array}$ & $\begin{array}{l}\text { 117- } \\
\text { Glu** }\end{array}$ & - & - & - & $\begin{array}{l}117- \\
\text { Glu** }\end{array}$ & $\begin{array}{l}\text { 117- } \\
\text { Glu** }^{* *}\end{array}$ & - & - & $\begin{array}{l}\text { 117- } \\
\text { Glu** }\end{array}$ \\
\hline & - & - & - & $\begin{array}{l}118- \\
\text { Trp }^{* *}\end{array}$ & - & - & - & - & - & - & - & - \\
\hline & - & - & $\begin{array}{l}\text { 135- } \\
\text { Asn" }\end{array}$ & - & - & - & - & - & - & - & - & $\begin{array}{l}\text { 135- } \\
\text { Asn }\end{array}$ \\
\hline & - & - & - & - & $\begin{array}{l}\text { 161- } \\
\text { Gln }\end{array}$ & - & - & - & - & - & - & - \\
\hline & - & - & - & - & $\begin{array}{l}248- \\
\text { Ser }^{* *}\end{array}$ & - & - & - & - & - & - & 25 \\
\hline & - & - & - & - & - & - & - & - & - & - & - & $\begin{array}{l}250- \\
\text { Pro* }\end{array}$ \\
\hline & - & - & $\begin{array}{l}251- \\
\text { Gln }\end{array}$ & - & $\begin{array}{l}251- \\
G \ln ^{*+\ldots+*}\end{array}$ & - & - & - & - & - & - & $\begin{array}{l}251- \\
\mathrm{Gln}\end{array}$ \\
\hline & - & - & $\begin{array}{l}253- \\
\text { Pro }\end{array}$ & - & - & - & - & - & - & - & - & $\begin{array}{l}\text { 253- } \\
\text { Pro** }\end{array}$ \\
\hline & - & $\begin{array}{l}\text { 254- } \\
\text { Trp" }\end{array}$ & $\begin{array}{l}\text { 254- } \\
\text { Trp" }\end{array}$ & $\begin{array}{l}\text { 254- } \\
\operatorname{Trp}^{* \text { *tokt }}\end{array}$ & - & - & - & $\begin{array}{l}254- \\
\text { Pro" }\end{array}$ & $\begin{array}{l}\text { 254- } \\
\text { Pro" }\end{array}$ & - & - & $\begin{array}{l}\text { 254- } \\
\text { Pro* }\end{array}$ \\
\hline & - & - & - & $\begin{array}{l}\text { 255- } \\
\text { Glu* }\end{array}$ & - & - & - & $\begin{array}{l}\text { 255- } \\
\text { Glu* }\end{array}$ & $\begin{array}{l}\text { 255- } \\
\text { Glu* }\end{array}$ & - & - & - \\
\hline & - & - & - & $\begin{array}{l}\text { 257- } \\
\text { Lys }\end{array}$ & - & - & - & - & $\begin{array}{l}\text { 257- } \\
\text { Lys }\end{array}$ & - & - & - \\
\hline & - & - & - & $\begin{array}{c}258- \\
\text { Asp }^{* *+* k * * *}\end{array}$ & - & - & - & $\begin{array}{c}258- \\
\text { Asp }^{* * * *}\end{array}$ & $\begin{array}{l}258- \\
\text { Asp }^{* * * * *}\end{array}$ & - & - & - \\
\hline & - & - & - & $\begin{array}{l}\text { 259- } \\
\text { Ala** }\end{array}$ & - & - & - & - & $\begin{array}{l}\text { 259- } \\
\text { Ala** }\end{array}$ & - & - & - \\
\hline & - & $\begin{array}{l}\text { 260- } \\
\text { Trp }\end{array}$ & - & $\begin{array}{l}\text { 260- } \\
\text { Trp"* }\end{array}$ & - & - & - & $\begin{array}{l}260- \\
\text { Trp }\end{array}$ & $\begin{array}{l}260- \\
\text { Trp* }\end{array}$ & - & - & - \\
\hline & $\begin{array}{l}273- \\
\text { Leu* }\end{array}$ & - & - & - & - & $\begin{array}{l}273- \\
\text { Leu }^{* *}\end{array}$ & $\begin{array}{l}\text { 273- } \\
\text { Leu }^{* *}\end{array}$ & . & - & $\begin{array}{l}\text { 273- } \\
\text { Leu* }\end{array}$ & $\begin{array}{l}\text { 273- } \\
\text { Leu* }^{*}\end{array}$ & - \\
\hline & $\begin{array}{l}274- \\
\text { Gly" }\end{array}$ & - & - & - & - & - & - & - & - & $\begin{array}{l}\text { 274- } \\
\text { Gly" }\end{array}$ & - & - \\
\hline & - & - & - & - & - & - & - & - & - & $\begin{array}{l}275- \\
\text { Alatotet }\end{array}$ & - & - \\
\hline & $\begin{array}{l}276- \\
\text { Gly" }\end{array}$ & - & - & - & - & $\begin{array}{l}276- \\
\text { Gly* }\end{array}$ & $\begin{array}{l}\text { 276- } \\
\text { Gly" }\end{array}$ & - & - & $\begin{array}{l}276- \\
\text { Gly" }\end{array}$ & $\begin{array}{l}276- \\
\text { Gly }^{* *}\end{array}$ & - \\
\hline & $\begin{array}{l}277- \\
\text { Gln"* }\end{array}$ & - & - & - & - & $\begin{array}{l}277- \\
\text { Gln }\end{array}$ & $\begin{array}{l}277- \\
\text { Gln }\end{array}$ & - & - & - & - & - \\
\hline & $\begin{array}{l}281- \\
\text { Val }^{*}\end{array}$ & - & - & - & - & $\begin{array}{l}281- \\
\text { Val }^{\text {s*t }}\end{array}$ & $\begin{array}{l}281- \\
\text { Val }^{\text {tow }}\end{array}$ & - & - & $\begin{array}{l}\text { 281- } \\
\mathrm{Val}^{*}\end{array}$ & $\begin{array}{l}281- \\
\mathrm{Val}^{\text {***t }}\end{array}$ & - \\
\hline & $\begin{array}{l}293- \\
\text { Ala" }\end{array}$ & - & - & - & - & $\begin{array}{l}293- \\
\text { Ala" }\end{array}$ & $\begin{array}{l}\text { 293- } \\
\text { Ala" }\end{array}$ & - & - & $\begin{array}{l}293- \\
\text { Ala* }\end{array}$ & $\begin{array}{l}\text { 293- } \\
\text { Ala** }\end{array}$ & - \\
\hline & $\begin{array}{l}295- \\
\text { Lys }^{* * *}\end{array}$ & - & - & - & - & $\begin{array}{l}\text { 295- } \\
\text { Lys }\end{array}$ & $\begin{array}{l}295- \\
\text { Lys }\end{array}$ & - & - & $\begin{array}{l}\text { 295- } \\
\text { Lys }\end{array}$ & $\begin{array}{l}\text { 295- } \\
\text { Lys }\end{array}$ & - \\
\hline & - & $\begin{array}{l}\text { 315- } \\
\text { Lys }^{\text {*tskt }}\end{array}$ & - & $\begin{array}{l}\text { 315- } \\
\text { Lys* }\end{array}$ & - & - & - & $\begin{array}{l}315- \\
\text { Lys* }\end{array}$ & $\begin{array}{l}315- \\
\text { Lys* }^{*}\end{array}$ & - & - & - \\
\hline & - & - & - & $\begin{array}{l}316- \\
\mathrm{His}^{* *}\end{array}$ & - & - & - & - & - & - & - & - \\
\hline & - & $\begin{array}{l}318- \\
\text { Gln }\end{array}$ & $\begin{array}{l}318- \\
\mathrm{G} \ln ^{* * *}\end{array}$ & $\begin{array}{l}318- \\
\mathrm{G} \ln ^{*+*+*}\end{array}$ & - & - & - & $\begin{array}{l}\text { 318- } \\
\text { Gln }\end{array}$ & $\begin{array}{l}318- \\
\mathrm{G} \ln ^{* * *}\end{array}$ & - & - & $\begin{array}{l}318- \\
\text { Gln }\end{array}$ \\
\hline & - & - & $\begin{array}{l}319- \\
\mathrm{His}^{* *}\end{array}$ & - & - & - & - & - & - & - & - & $\begin{array}{l}319- \\
\mathrm{His}^{* *}\end{array}$ \\
\hline & - & - & $\begin{array}{l}320- \\
\text { Asp }^{* *}\end{array}$ & - & $\begin{array}{l}320- \\
\text { Asp }^{* * *}\end{array}$ & - & - & - & - & - & - & $\begin{array}{l}320- \\
\text { Asp }^{* *}\end{array}$ \\
\hline & - & - & - & - & $\begin{array}{l}321- \\
\text { Lys }\end{array}$ & - & - & - & - & - & - & - \\
\hline & $\begin{array}{l}323- \\
\text { Val }^{\text {t** }}\end{array}$ & - & - & - & - & - & - & - & - & $\begin{array}{l}323- \\
\mathrm{Val}^{* *}\end{array}$ & - & - \\
\hline
\end{tabular}

Das: dasatinib; *Alkyl/Pi-alkyl interaction; **Van der Waals interaction; ***Pi-sigma interaction; ****Hydrogen bond; *****Pi-cation/anion; ******Unfavorable bump/donor-donor 


\section{DISCUSSION}

The docking protocol is done by using energy range 3 , exhaustiveness 18 , and the number of modes 9. In addition to exhaustiveness, values for other parameters were the default values of Autodock Vina. The value of exhaustiveness is increased from 8 to 18 to increase the robustness of the docking performed (Forli, et al., 2016). Molecular docking was performed using configuration settings similar to the validation process with changes to the test ligand file used (Ravindranath, et al., 2015). One interesting finding is that of all the test ligands used, the four that have an affinity value that can be compared with quercetin are berberine, columbamine, jatrorrhizine, and palmatine. The four ligands have structural similarities to the benzylisoquinoline parent group with different variations of the hydroxy and methoxy groups in substituents number $2,3,9$, and 10 . Whereas specifically for berberine, it is replaced with 1,3-benzodioxole groups (Khan \& Kumar, 2015). In addition to the structural similarities, the four compounds are also known to have anticancer activity, one of which is quite well known is berberine. Berberine has even been marketed in oral dosage forms such as capsules and is used in various types of therapies such as diabetes, dyslipidemia, and as vitamins, although no preparations have been produced with indications as anticancer (Neag, et al., 2018). The development of berberine derivatives itself is still underway, one of which is by making derivatives with more potent anticancer activities (Pratama \& Pratomo, 2017). While from the test ligands, the highest similarity was shown by jatrorrhizine, with $93.33 \%$ similar amino acid residues and $53.33 \%$ similar types of interactions compared to quercetin. In addition, jatrorrhizine also showed a very high similarity to dasatinib with $73.91 \%$ similarity of amino acid residues and $56.52 \%$ similarity of interaction types. The berberine ranks only third with the highest similarity for quercetin and dasatinib. The high amino acid residue similarity and interaction of jatrorrhizine increases the probability that jatrorrhizine will have activity as an Src inhibitor with a mechanism of action similar to quercetin and dasatinib. Moreover, the value of $\Delta \mathrm{G}$ jatrorrhizine itself is higher than Quercetin and only $0.1 \mathrm{kcal} / \mathrm{mol}$ adrift of dasatinib. One of the causes of the high similarity is that jatrorrhizine interacts with a lot of amino acids which are 18 in number, most compared to other test ligands. The more significant number of interactions of amino acid residues will undoubtedly increase the probability of similarity in types of interactions, while also potentially increasing ligand affinity (Araujo \& Logothetis, 2010; Luscombe, et al., 2001). The main difference in the interactions between berberine and jatrorrhizine is due to the orientation of the benzodioxole group of berberine at different binding sites with the methoxy and hydroxyl groups of jatrorrhizine. The methoxy group itself has higher torque so it can move more freely than the more rigid benzodioxole group. Hence more amino acid residues can interact (Gupta, et al., 2009). However, even though Jatrorrhizine has more interactions than berberine, berberine still has a higher affinity, which indicates that the interactions of the benzodioxole group are relatively stronger (Papi, et al., 2017). It is interesting to observe whether berberine will also produce interactions similar to jatrorrhizine, considering the similarity levels of amino acid residues with both quercetin and dasatinib are also relatively high. Therefore, a combination of berberine and jatrorrhizine has the potential to be used to obtain optimal Src inhibitory activity.

\section{CONCLUSION}

This study successfully demonstrated that among the secondary metabolites of other akar kuning, the highest potential for Src inhibitors was demonstrated by berberine and jatrorrhizine. While berberine shows higher affinity compared to reference compounds such as quercetin and dasatinib, jatrorrhizine shows very high amino acid interaction similarities with the reference ligand. 
The combination of both is expected to optimize the activity of the resulting Src inhibitors. Furthermore, further in vitro research including toxicity assay can be carried out to prove the potential of the combination of the two as Src inhibitors.

\section{ACKNOWLEDGMENT}

This work was supported by the internal research grant with a scheme Penelitian Kompetitif Dosen Internal (Competitive Research of Internal Lecturers) Universitas Muhammadiyah Palangkaraya in 2019 from the Institute for Research and Community Services Universitas Muhammadiyah Palangkaraya.

\section{REFERENCES}

Araujo, J. and Logothetis, C., 2010, Dasatinib: a potent SRC inhibitor in clinical development for the treatment of solid tumors, Cancer Treat. Rev., 36(6), 492-500.

Ardito, F., Giuliani, M., Perrone, D., Troiano, G. and Muzio, L.L., 2017, The crucial role of protein phosphorylation in cell signaling and its use as targeted therapy (Review), Int. J. Mol. Med., 40(2), 271-280.

Atkovska, K., Samsonov, S.A., Paszkowski-Rogacz, M. and Pisabarro, M.T., 2014, Multipose Binding in Molecular Docking, Int. J. Mol. Sci., 15(2), 2622-2645.

Bhullar, K.S., Lagaron, N.O., McGowan, E.M., Parmar, I., Jha, A., Hubbard, B.P. and Rupasinghe, H.P.V., 2018, Kinase-targeted cancer therapies: progress, challenges and future directions, Mol. Cancer, 17, 48.

Castro-Alvarez, A., Costa, A.M. and Vilarrasa, J., 2017, The Performance of Several Docking Programs at Reproducing Protein-Macrolide-Like Crystal Structures, Molecules, 22(1), E136.

Ferreira, L.G., dos Santos, R.N., Oliva, G. and Andricopulo, A.D., 2015, Molecular docking and structure-based drug design strategies, Molecules, 20(7), 13384-13421.

Forli, S., 2015, Charting a Path to Success in Virtual Screening, Molecules, 20(10), 18732-18758.
Forli, S., Huey, R., Pique, M.E., Sanner, M., Goodsell, D.S. and Olson, A.J., 2016, Computational protein-ligand docking and virtual drug screening with the AutoDock suite, Nat. Protoc., 11(5), 905-919.

Ginovyan, M., Petrosyan, M. and Trchounian, A., 2017, Antimicrobial activity of some plant materials used in Armenian traditional medicine, BMC Complement. Altern. Med., 17, 50.

Gupta, D., Gupta, S.V., Lee, K.D. and Amidon, G.L., 2009, Chemical and enzymatic stability of amino acid prodrugs containing methoxy, ethoxy and propylene glycol linkers, Mol. Pharm., 6(5), 1604-1611.

Haryanti, S. and Widiyastuti, Y., 2017, Aktivitas Sitotoksik pada Sel MCF-7 dari Tumbuhan Indonesia untuk Pengobatan Tradisional Kanker Payudara, Media Penelitian Pengembangan Kesehatan, 27(4), 247-254.

Khan, A.Y. and Kumar, G.S., 2015, Natural isoquinoline alkaloids: binding aspects to functional proteins, serum albumins, hemoglobin, and lysozyme, Biophys. Rev., 7(4), 407-420.

Long, J., Song, J., Zhong, L., Liao, Y., Liu, L. and Li, X., 2019, Palmatine: A review of its pharmacology, toxicity and pharmacokinetics, Biochimie, 162, 176-184.

Lu, J.J., Bao, J.L., Chen, X.P., Huang, M. and Wang, Y.T., 2012, Alkaloids Isolated from Natural Herbs as the Anticancer Agents, Evid. Based Complement. Alternat. Med., 2012, 485042.

Luscombe, N.M., Laskowski, R.A. and Thornton, J.M., 2001, Amino acid-base interactions: a three-dimensional analysis of protein-DNA interactions at an atomic level, Nucleic Acids Res., 29(13), 2860-2874. Mahavorasirikul, W., Viyanant, V., Chaijaroenkul, W., Itharat, A. and Na-Bangchang, K., 2010, Cytotoxic activity of Thai medicinal plants against human cholangiocarcinoma, laryngeal and hepatocarcinoma cells in vitro, BMC Complement. Altern. Med., 10, 55. Megantara, S., Iwo, M.I., Levita, J. and Ibrahim, S., 2016, Determination of ligand position in aspartic proteases by correlating Tanimoto coefficient and binding affinity with root mean square deviation, J. Appl. Pharm. Sci., 6(1), 125-129. Morris, G.M., Huey, R., Lindstrom, W., Sanner, M.F., 
Belew, R.K., Goodsell, D.S. and Olson, A.J., 2009, AutoDock4 and AutoDockTools4: Automated docking with selective receptor flexibility, J. Comput. Chem., 30(16), 2785-2791.

Natesan, S., Subramaniam, R., Bergeron, C. and Balaz, S., 2012, Binding affinity prediction for ligands and receptors forming tautomers and ionization species: inhibition of mitogen-activated protein kinase-activated protein kinase 2 (MK2), J. Med. Chem., 55(5), 2035-2047.

Neag, M.A., Mocan, A., Echeverria, J., Pop, R.M., Bosca, C.I., Crisan, G. and Buzoianu, A.D., 2018, Berberine: Botanical Occurrence, Traditional Uses, Extraction Methods, and Relevance in Cardiovascular, Metabolic, Hepatic, and Renal Disorders, Front. Pharmacol., 9, 557.

O’Boyle, N.M., Banck, M., James, C.A., Vandermeersch, T. and Hutchison, G.R., 2011, Open Babel: An open chemical toolbox, J. Cheminformatics, 3, 33.

Pagadala, N.S., Syed, K. and Tuszynski, J., 2017, Software for molecular docking: a review, Biophys. Rev., 9(2), 91-102.

Papi, F., Ferraroni, M., Rigo, R., da Ros, S., Bazzicalupi, C., Sissi, C. and Gratteri, P., 2017, Role of the Benzodioxole Group in the Interactions between the Natural Alkaloids Chelerythrine and Coptisine and the Human Telomeric G-Quadruplex DNA. A Multiapproach Investigation, J. Nat. Prod., 80(12), 3128-3135.

Pettersen, E.F., Goddard, T.D., Huang, C.C., Couch, G.S., Greenblatt, D.M., Meng, E.C. and Ferrin, T.E., 2004, UCSF Chimera--a visualization system for exploratory research and analysis, J. Comput. Chem., 25(13), 1605-1612.

Pratama, M.R.F., 2016, Akar Kuning (Arcangelisia flava) sebagai Inhibitor EGFR: Kajian In Silico, Jurnal Farmagazine, 3(1), 6-16.

Pratama, M.R.F. and Pratomo, G.S., 2017, Pharmacophore Optimization of Berberine as HER2 Inhibitor, Jurnal Farmasi Indonesia, 14(2), 109-117.

Pratama, M.R.F., Suratno, S. and Mulyani, E., 2018, Antibacterial Activity of Akar Kuning (Arcangelisia flava) Secondary Metabolites: Molecular Docking Approach, Asian. J. Pharm. Clin. Res., 11(11), 447-451.
Pratama, M.R.F. and Sutomo, S., 2018, Chemical Structure Optimization of Lupeol as ER-î‘ and HER2 Inhibitor,Asian. J.Pharm. Clin. Res., 11(6), 298-303.

Qiu, H., Sun, S., Ma, X., Cui, C., Chen, G., Liu, Z., Li, H. and Liu, M., 2018, Jatrorrhizine Hydrochloride Suppresses Proliferation, Migration, and Secretion of Synoviocytes In Vitro and Ameliorates Rat Models of Rheumatoid Arthritis In Vivo, Int. J. Mol. Sci., 19(5), E1514.

Rad, S.Z.K., Rameshrad, M. and Hosseinzadeh, H., 2017, Toxicology effects of Berberis vulgaris (barberry) and its active constituent, berberine: a review, Iran. J. Basic Med. Sci., 20(5), 516-529.

Ramirez, D. and Caballero, J., 2018, Is It Reliable to Take the Molecular Docking Top Scoring Position as the Best Solution without Considering Available Structural Data?, Molecules, 23(5), 1038.

Ravindranath, P.A., Forli, S., Goodsell, D.S., Olson, A.J. and Sanner, M.F., 2015, AutoDockFR: advances in protein-ligand docking with explicitly specified binding site flexibility, PLOS Comput. Biol., 11(12), e1004586.

Sicheri, F., Moarefi, I. and Kuriyan, J., 1997, Crystal structure of the Src family tyrosine kinase Hck, Nature, 385(6617), 602-609.

Singh, H., Srivastava, H.K. and Raghava, G.P.S., 2016, A web server for analysis, comparison and prediction of protein ligand binding sites, Biol. Direct., 11, 14.

Talpaz, M., Saglio, G., Atallah, E. and Rousselot, P., 2018, Dasatinib dose management for the treatment of chronic myeloid leukemia, Cancer, 124(8), 1660-1672.

Trott, O. and Olson, A.J., 2010, AutoDock Vina: improving the speed and accuracy of docking with a new scoring function, efficient optimization and multithreading, J. Comput. Chem., 31(2), 455-461.

Wee, P. and Wang, Z., 2017, Epidermal Growth Factor Receptor Cell Proliferation Signaling Pathways, Cancers, 9(5), 52.

Yi, F., Li, L., Xu, L.J., Meng, H., Dong, Y.M., Liu, H.B. and Xiao, P.G., 2018, In silico approach in reveal traditional medicine plants pharmacological material basis, Chin. Med., 13, 33.

Yuan, S., Chan, S. and Hu, Z., 2017, Using PyMOL as a platform for computational drug design, Wiley Interdiscip. Rev. Comput. Mol. Sci. , 7(2), e1298. 